\title{
EDUKASI GERAKAN 5M PADA ANAK USIA DINI GUNA PENCEGAHAN COVID-19 MELALUI BUKU CERITA BERGAMBAR
}

\author{
Prabawati Nurhabibah*, Dewi Yulianawati \\ Pendidikan Guru Sekolah Dasar Fakultas Keguruan dan Ilmu Pendidikan \\ Universitas Muhammadiyah Cirebon, Indonesia \\ *prabawati@umc.ac.id
}

\begin{abstract}
This service is motivated by the author's concern as a researcher as well as a parent who has early childhood that there will be a new variant of the Covid-19 virus that continues to mutate. Based on this, education about preventing the transmission of the Covid-19 virus needs to be given to early childhood, given the findings as of July 2021 there were 777 children in Indonesia who died due to COVID-19. The highest percentage of mortality rate (CFR) is in the 0-2 year age group, followed by the 16-18 year age group and the 3-6 year age group. Storytelling is one of the fun learning methods for children, so the purpose of implementing the 5M Movement education (wearing masks, washing hands, keeping distance, avoiding crowds, and limiting mobility) is expected to be easily applied in children's lives.
\end{abstract}

Keywords: 5 m movement; covid-19; storytelling

\begin{abstract}
Abstrak
Pengabdian ini dilatarbelakangi oleh kekhawatiran penulis sebagai peneliti sekaligus orang tua yang memiliki anak-anak usia dini akan adanya varian baru dari virus covid-19 yang terus bermutasi. Berdasarkan hal tersebut edukasi mengenai pencegahan penularan virus Covid-19 ini perlu diberikan untuk anak usia dini, mengingat adanya temuan per Juli 2021 terdapat 777 anak di Indonesia meninggal dunia akibat COVID-19. Persentase Angka Kematian Tertinggi (CFR) berada pada kelompok usia 0-2 tahun, diikuti kelompok usia 1618 tahun dan usia 3-6 tahun. Bercerita adalah salah satu metode pembelajaran yang menyenangkan untuk anak-anak, sehingga tujuan dari dilaksanakannya edukasi Gerakan 5M (Memakai masker, mencuci tangan, menjaga jarak, menjauhi kerumunan, dan membatasi mobilitas) diharapkan akan dapat dengan mudah diaplikasikan dalam kehidupan anak-anak. Melalui instrument berupa angket "Ayo LAwan Virus Corona" dapat diketahui bahwa buku cerita bergambar dapat memberikan pemahaman $100 \%$ kepada siswa mengenai kebiasaan baik yang harus dilakukan untuk mencegah virus Covid-19. Dengan kata lain, kegiatan pengabdian yang dilakukan ini dapat memberikan pengetahuan dan pemahaman kepada anak usia dini mengenai penyebaran dan pencegahan covid-19 dalam melakukan aktivitas keseharian.
\end{abstract}

Kata Kunci: gerakan 5m; covid-19; buku cerita

\begin{tabular}{l|l|l} 
Submitted: $2021-09-23$ & Revised: $2021-10-26$ & Accepted: $2021-10-30$
\end{tabular}

\section{Pendahuluan}

Data Satgas Penanganan COVID-19 mengungkapkan secara kumulatif hingga 16 Juli 2021 ada 777 anak di Indonesia meninggal dunia akibat COVID-19. Persentase Angka Kematian Tertinggi (CFR) berada pada kelompok usia 0-2 tahun, diikuti kelompok usia 16-18 tahun dan usia 3-6 tahun (Litha, 2021).

Kurangnya pemahaman anak terhadap Covid-19 dan pencegahannya dikarenakan penyampaian atau media informasi belum sesuai tingkat pemahaman anak menyebabkan mereka melakukan aktivitas sehari-hari tanpa mematuhi protokol kesehatan pencegahan Covid-19. Interaksi antar anak saat bermain memungkinkan risiko penularan virus Covid-19 (Fitriani et all, 2020).

Anak-anak termasuk golongan yang rentan terpapar Covid-19. Sekalipun mereka hanya mengalami gejala ringan atau bahkan tidak bergejala, tetapi sangat dimungkinkan mereka menjadi fasilitator penyebaran virus. Anak-anak terutama yang masih berada di usia golden age akan sangat mudah untuk menirukan dan menerima rangsangan. Mereka perlu diarahkan untuk berperilaku sehat dan diedukasi tentang Covid-19 supaya bisa menghindarkan diri mereka dari risiko terpapar dan memaparkan kepada orang lain terutama keluarganya sebagai wadah sosial utama mereka (Kelvin \& Halperin, 2020). 
Fenomena tersebut tentu mendapat respon dari penulis untuk memulai mengedukasi anakanak dengan menciptakan sebuah media buku cerita bergambar sebagai upaya pencegahan Covid19. Penulis menyadari bahwa edukasi pencegahan covid-19 kepada anak harus disampaikan dengan metode yang ringan dan menyenangkan sehingga tidak mempengaruhi psikologis anak.

Beberapa penelitian tentang sosialisasi pencegahan Covid-19 pada anak-anak sudah banyak dilakukan di antaranya Yulianingsih, dkk (2020) berjudul Pengenalan Covid-19 pada Anak Usia Dini melalui Metode Bercerita. Selain itu Ambarsari, dkk (2021) pernah meneliti Edukasi Pencegahan Penularan Virus Corona Kepada Anak- Anak dengan Gerakan 3M. Fitriani, dkk (2020) dengan judul Ed.Cofid (Education Covid-19 For Kids) Dalam Rangka Pencegahan Penyebaran Virus Covid-19 Kepada Anak-Anak Sekolah Dasar Di Desa Wonorejo Karanganyar Demak. Wardhani, dkk (2020) tentang Edukasi Pencegahan Penularan COVID-19 Pada Anak Usia Dini Melalui Media Pembelajaran Audio Visual. Dan Faslia, dkk (2021) mengenai Sosialisasi Penerapan Protokol Kesehatan di SD Negeri 10 Gu Buton Tengah.

Sementara itu, penelitian mengenai Edukasi 5M pada Anak Usia Dini Guna Pencegahan Covid19 melalui Buku Cerita Bergambar belum pernah dilakukan. Sehingga hasil penelitian ini diharapkan dapat menjadi rujukan bagi para guru di lingkungan pendidikan anak usia dini baik PAUD maupun TK untuk mengenalkan pencegahan Covid-19 melalui Gerakan 5M (memakai masker, mencuci tangan, menjaga jarak, menjauhi kerumunan, dan membatasi interaksi sosial) dengan metode bercerita melalui media buku cerita bergambar.

\section{Metode}

Metode pelaksanaan pengabdian yang dilakukan di antaranya adalah:

\section{Persiapan}

Persiapan yang dilakukan adalah mengumpulkan dan menyusun materi cerita mengenai gerakan 5M (memakai masker, mencuci tangan, menjaga jarak, menjauhi kerumunan, dan membatasi interaksi sosial) yang akan dibuat dalam sebuah buku agar dapat disampaikan pada anak-anak usia dini.

\section{Sosialisasi dan Edukasi}

Sosialisasi dan edukasi dilakukan pada anak-anak usia dini dengan membacakan buku cerita bergambar yang berisi pengenalan gerakan 5M (memakai masker, mencuci tangan, menjaga jarak, menjauhi kerumunan, dan membatasi interaksi sosial)

3. Evaluasi

Evaluasi yang dilakukan bertujuan untuk mengetahui keberhasilan pelaksanaan kegiatan edukasi pencegahan Covid-19 pada anak usia dini melalui buku cerita bergambar.

Kegiatan Pengabdian Masyarakat yang dilakukan oleh Dosen dan Mahasiswa ini merupakan Program Kompetisi Kampus Merdeka (PKKM) dari Univeristas Muhammadiyah Cirebon yang bertujuan untuk mengedukasi peserta didik anak usia dini agar terciptanya kepekaan dan kesadaran akan adanya bahaya covid-19 dan cara pencegahannya.

Lembaga Pendidikan yang terpilih sebagai mitra untuk melaksanakan pengabdian ini adalah TK Pembangunan yang terletak di Kecamatan Mandirancan Kabupaten Kuningan Jawa Barat.

Berikut ini tabel peserta yang mengikuti kegiatan sosialisasi edukasi Gerakan 5M guna pencegahan covid-19 pada anak usia dini beserta jumlah anggotanya.

Tabel 1. Tabel Peserta

\begin{tabular}{lll}
\hline No & Kelas & Jumlah \\
\hline 1 & TK Kelas A & 17 Siswa \\
2 & TK Kelas B & 15 Siswa \\
\hline
\end{tabular}




\section{Hasil dan Pembahasan}

Penyebaran virus, seperti flu, batuk dan bahkan virus Covid-19 dapat terjadi di berbagai tempat. Penyebaran virus Covid-19 ini menjadi bencana global yang harus mendapatkan perhatian dari seluruh lapisan masyarakat, sehingga perlu adanya ketegasan dalam menerapkan pencegahan penyebaran Covid-19. Salah satu tempat yang berpotensi bagi penyebaran virus adalah sekolah, terutama Taman Kanak-kanak yang siswanya masih suka sembarangan dalam menyentuh bendabenda yang tidak steril baik di luar sekolah maupun di dalam sekolah.

Taman Kanak-kanak yang menjadi sasaran kegiatan pengabdian ini sudah melakukan berbagai upaya yang dilakukan dalam pencegahan Covid-19 yaitu pengecekan suhu, gerakan wajib memakai masker, pemasangan tempat cuci tangan, dan bahkan melarang orang tua siswa untuk menunggu di dalam lingkungan sekolah agar tidak berkerumun. Namun, dari upaya yang telah dibuat, kesadaran anak usia dini terhadap bahaya Covid -19 masih kurang baik, Berdasarkan hasil wawancara dengan salah satu guru di sekolah bahwa sekolah melakukan berbagai upaya untuk pencegahan Covid-19, akan tetapi sekolah tidak bisa mengontrol aktivitas keseharian siswa di luar lingkungan sekolah. Oleh karena itu, kegiatan pengabdian ini dilakukan dalam bentuk sosialisasi dan edukasi melalui buku cerita. Buku tersebut menceritakan kebiasaan baik yang harus dialkukan oleh para siswa dalam menjalani aktivitas sehari-hari.

Kegiatan sosialisasi dan edukasi pada kegiatan pengabdian ini dilakukan secara luring. Para siswa di Taman Kanak-kanak diminya untuk menyimak cerita terkait dengan pencegahan virus Covid-19. Isi cerita dalam buku yang berjudul "Lima Kebiasaan Baik untuk Melawan Virus Jahat" disampaikan kepada dua kelompok A dan B.

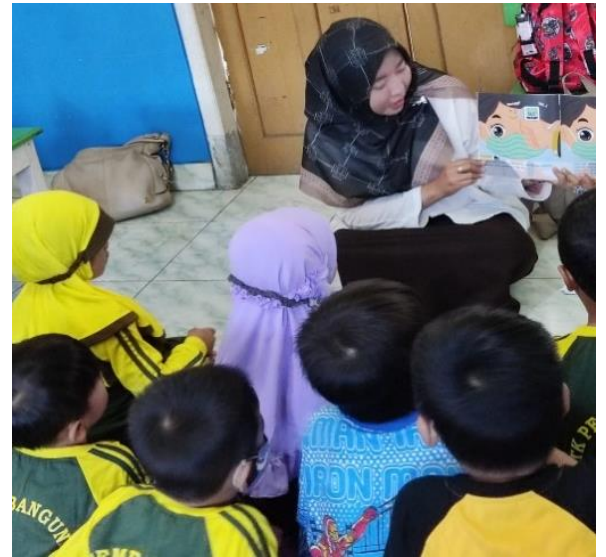

Gambar 1. Kegiatan Bercerita pada Kelompok A

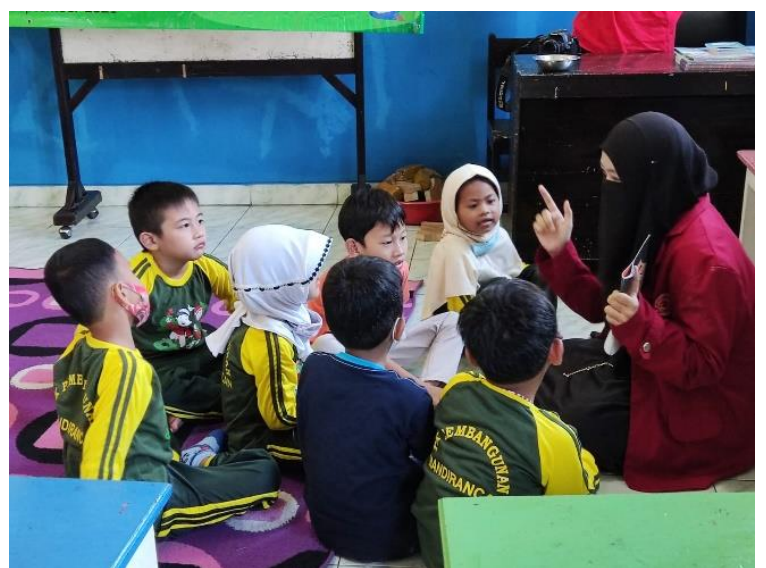

Gambar 2. Kegiatan Bercerita pada Kelompok B

Melalui Gambar 1 dan Gambar 2 mennunjukkan bahwa siswa memiliki antusias yang tinggi terhadap isi buku cerita yang disampaikan oleh narasumber. Cerita yang disampaikan meliputi kebiasaan baik yang dapat dilakukan untuk mencegah penyebaran Covid-19 di antaranya; 1) memakai masker (M1), 2) mencuci tangan dengan sabun (M2), 3) menjaga jarak (M3), 4) menghindari kerumunan (M4), 5) membatasi bepergian (M5).

Tahap evaluasi dilakukan setelah kegiatan sosialisasi dan edukasi yang bermaksud untuk melihat ketercapaian tujuan dari kegiatan pengabdian. Angket yang berjudul "Ayo Lawan Virus Corona" digunakan untuk mengukur pemahaman anak usia dini terhadap pencegahan virus Covid19 yang terdiri dari lima bagian (5M). Setiap bagian disajikan pilihan gambar yang menunjukkan kebiasan baik dan tidak baik dalam melakukan aktivitas keseharian seperti pada Gambar 3. Para siswa memberikan tanda checklist pada salah satu gambar yang dianggap benar untuk mencegah Covid-19, dengan dbantu diberikan arahan tambahan untuk mengisi angket tersebut. 

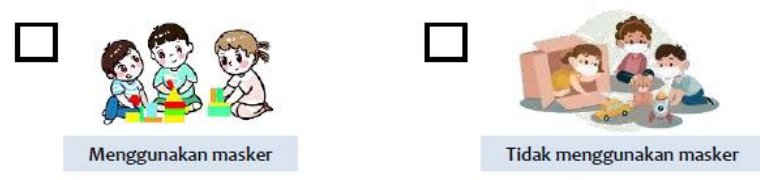

Gambar 3. Contoh Pilihan Gambar pada Angket

Berdasarkan hasil rekapitulasi angket pada Gambar 4 menunjukkan bahwa 100\% siswa menjawab benar, dengan kata lain siswa sudah memahami kebiasaan baik yang harus dilakukan untuk pencegahan Covid-19 untuk setiap aspek 5M. Hasil ini sesuai dengan kegiatan pengabdian yang telah dilakukan oleh Wardhini (2020) bahwa dengan menggunakan media audio visual dapat memberikan pemahaman $100 \%$ kepada siswa mengenai pencegahan penularan Covid-19 pada anak usia dini. Harapannya setelah kegiatan ini, para siswa selain mendapatkan pengetahuan tentang pencegahan covid dan lebih menyadari pentingnya melakukan 5M, melainkan dapat menerapkan kebiasaan 5M dalam menjalani aktivitas keseharian.

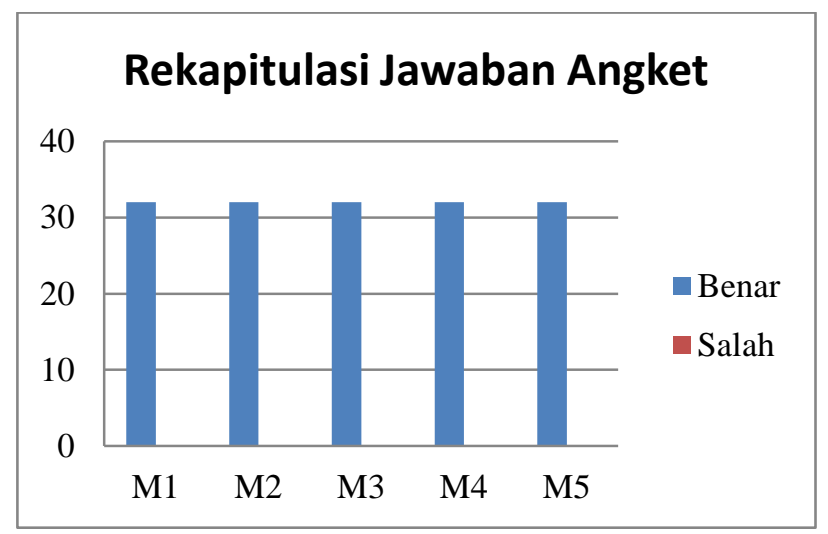

Gambar 4. Hasil Rekapitulasi Angket

\section{Kesimpulan}

Kegiatan pengabdian kepada masyarakat mengenai berupa edukasi pencegahan Covid-19 melalui buku cerita bergambar. Kegiatan ini dilaksanakan falam bentuk edukasi, pemberian materi melalui cerita isi buku bergambar secara luring. Berdasarkan hasil kegiatan bahwa saat sebelum dibacakan isi cerita buku bergambar, pengetahuan anak usia dini tentang penyebaran covid-19 ketika mengabaikan 5M masih kurang. Melalui buku cerita bergambar, anak usia dini dapat memahami kebiasaan baik yang harus dilakukan untuk mencegah covid-19. Selain itu para siswa juga memahami bagaimana penyebaran dan penularan virus ketika kebiasaan baik tidak dilakukan dalam menjalani aktivitas keseharian. Kebiasaan baik itu meliputi gerakan 5M (memakai masker, mencuci tangan, menjaga jarak, menjauhi kerumunan, dan membatasi interaksi sosial).

\section{Daftar Pustaka}

Ambarsari, R.Y. \& Sasmito, L.F., (2021), Edukasi Pencegahan Penularan Virus Corona kepada Anak-anak dengan Gerakan 3M, PROFICO: Jurnal Pengabdian kepada Masyarakat, Vol. 2, No. $1, \mathrm{~h} / \mathrm{m}$. 70-75

Faslia,F., dkk., (2021), Sosialisasi Penerapan Protokol Kesehatan di SD Negeri 10 Gu Buton Tengah, Jurnal Abdidas, Vol. 2, No. 4, h/m. 730-736

Fitriani, A., dkk., (2020), Ed. Cofid (Education Covod-19 for Kids) dalam Rangka Pencegahan Penyebaran Virus Covid-19 kepada Anak-anak Sekolah Dasar di Desa Wonorejo Karanganyar Demak, (Online) https://kkn.unnes.ac.id diakses tanggal 1 Oktober 2021

Kelvin, A. A., \& Halperin, S. (2020). COVID-19 in children: the link in the transmission chain. The 
BERNAS:

Jurnal Pengabdian Kepada Masyarakat

[Vol. 2 No 4, 2021, pp. 977-981]

Lancet Infectious Diseases, 2066), 633-634. https://doi.org/10.1016/S1473-3099(20)30236-X

Litha, Yoanes. 2021. Diakses melalui https://www.voaindonesia.com/a/ribu-anak-di-indonesiaterpapar-covid-19/5974016.html (4 September 2021)

Yulianingsih, Y., dkk., (2020), Pengenalan Covid-19 pada Anak Usia Dini melalui Metode Bercerita, (Online) http://digilib.uinsgd.ac.id/ diakses tanggal 1 Oktober 2021. 